\title{
A REVIEW OF THE ANTHROPOLOGICAL LITERATURE IN ENGLISH ON THE PALESTINIAN HAMUULA AND THE STATUS OF WOMEN
}

\author{
Celia E. Rothenberg
}

\section{UNIVERSITY OF TORONTO}

The following is a survey of the anthropological literature in English on the Palestinian hamüla, the extended family or clan, and Palestinian women's lives in the West Bank. Both areas of the literature are in certain respects problematic; in particular, actors' agency and women's experiences are often overlooked. The article concludes by presenting the notion of social geography-a concept which looks at how the geographical location of neighbors, friends, and family, as well as ideas of relatedness, create ties and shape the way women practice and experience social relations. Recognizing the importance of social geography may provide a way of wedding these two areas of the literature and addressing some of its gaps.

This article provides a critical, historical overview of the anthropological literature in English on first, the Palestinian hamūla, the extended family in the widest sense, or clan, and, second, Palestinian women's lives in the West Bank. The division of this literature-the hamūla and women-echoes two of the "zones of theory" outlined by Lila Abu-Lughod in her review of anthropological studies of the Middle East (1989). These zones include theorizing on segmentary lineages (including the paradigm of patrilineal kinship) and, what Abu-Lughod provocatively terms, the harem, or women.

Abu-Lughod argues that these two theoretical areas are distinct and unequally matched areas of inquiry:

Nearly all the segmentation theorists are men, while nearly all those who theorize about women are women. ... In the former the theoretical distinctions are fine, in the latter theoretical debate is muted. And if the segmentation theorists are concerned exclusively with politics, narrowly defined to refer only to the public world of men, the scholars working on women begin with ... the study of women's sphere, the harem $(1989,288)$.

A careful review of these zones of theory with respect to the Palestinian case may assist scholars in developing new approaches to these (and other) dilemmas found in the literature. Indeed, issues of not only gender and 
theory but also agency are key to the review here. I discuss in the final section of this paper my research (July 1996 through August 1997) in the Palestinian West Bank village of Artas on the nature of family ties and women's lives. This research allows me to suggest ways in which theorizing on the hamūla and women may be bridged and some theoretical problems avoided.

I include here literature stretching roughly from the 1950s (with the exception of Hilma Granqvist's earlier works) to the present, although this is not an exhaustive review. In 1972, when Richard Antoun published his ethnography Arab Village: A Social Structural Study of a Transjordanian Peasant Community (1972), he wrote in the introduction that only three other anthropologists had published book-length studies of Arab villages in the Fertile Crescent at the time of his book's publication. These anthropologists included Hilma Granqvist $(1931 ; 1935 ; 1947 ; 1950 ; 1965)$, Abner Cohen (1965), and Abdullah Lutfiyya (1966). Henry Rosenfeld, although he had not published a book in English, had also written substantially on the area (1958; $1959 ; 1960 ; 1962 ; 1964 ; 1968 ; 1972)$. It is important to note that Granqvist and Lutfiyya did their work in the West Bank, while Cohen and Rosenfeld worked in Arab villages inside Israel's 1948 borders and Antoun (1972) in a Palestinian village in Jordan (the East Bank). The different historical circumstances of these areas make direct comparisons problematic. ${ }^{1}$

By the early 1980s a number of new studies on the Palestinians in the West Bank had appeared (for example, Escribano 1987; Migdal 1980b; Nakhleh and Sureik 1980; Tamari 1981), as had a significant number of studies of Palestinian women (see, for example, Antonius 1979; Giacaman

\footnotetext{
1 While some political scientists and sociologists have argued that the annexation of the West Bank in 1967 paralleled the situation of the Galilee in the 1950s after Israel's occupation of the area in 1948 (for example Jiryis 1976), differences between the two situations are significant and make direct comparison problematic. The Galilee is not under military occupation and accompanying restrictions in the same way as the West Bank. While this factor in some ways has entailed less hardship for villagers in the Galilee, it has also meant that they were not able to use the "open bridge policy" to the rest of the Arab world as were villagers in the West Bank. Thus the two areas have experienced very different trends in migration, with villagers in the Galilee leaving Israel as refugees for Lebanon, while villagers in the West Bank left for work in Amman, Kuwait, and other parts of the Arab world. Further, villagers in the Galilee were subject to different methods of Israeli control, measures which largely focused on manipulating members of the hamüla through the use of Local Councils.
} 
1982; Haddad 1980; Pedersen 1983 and others). ${ }^{2}$ More recent works on Palestinian women and society include Augustin 1993; Giacaman and Odeh 1988; Moors 1995; Moors and al. 1995; Najjar 1992; and Peteet 1991.

\section{The Hamūla: Early Approaches}

Stemming in large part from Rosenfeld's influential work on Palestinian villages inside Israel, early debates over the nature of the hamüla were framed in terms of understanding the hamüla as an essentialized patrilineage, "blood" group or, on the other hand, as a class structure. The differences between these points of view can also be understood as either an overreliance on, or radical departure from, the role of historical continuity of the hamüla. Correspondingly, the effects of the Jordanian (1948-1967) and Israeli occupations (1967-present) in the West Bank are thus under- or overemphasized, either through authors' silence about these occupations' effects on the structure of the hamūla or their assertion that the occupations were directly able to shape the Palestinian family with little resistance. Thus, the political consequences of occupation on Palestinian village and family social structure are underestimated or the role of the Palestinian peasantry in shaping their own lives is denied. Finally, these arguments rely primarily on the public expression of the hamūla, an arena dominated by men, thereby overlooking women's practices and perspectives.

Rosenfeld's perspective on the Palestinian hamūla emphasized it as a kind of social glue, held over from the past, manipulated by external pressures, and, in certain areas, subject to some degree of change. Rosenfeld thus described Palestinian villages as "largely dependent on wage labor, yet maintaining contact with the land, and cleaving to the traditional social relations based on control of land-we may term [them] a 'residual' peasantry" (Rosenfeld 1964, 228, emphasis mine). Rosenfeld stated this argument in greater detail in the following terms:

While the fact that they are a weak proletariat outside the village and backward agriculturists inside the village ties them economically to a weak and fluid 'residual' extended family structure, the internal politics of hamule factionalism, the marriage system of the control over women that is its expression, and bride price, which explains its terms, culturally and materially anchor these extended families and makes them an on-going structural fact. Briefly: the State places pressure on the villagers to

\footnotetext{
2 Journalists and non-academic professionals have also written extensively on Palestinian women, including Bendt and Downing (1982), Wallach (1990), and Warnock (1990). The intifada spawned numerous works including Hiltermann (1991), Lockman and Beinin (1989), McDowall (1989), Peretz (1990), and Schiff and Ya'ari (1990).
} 
preserve the existing order and supports traditional lineage combinations or picks their representatives $(1968,740)$.

Emphasizing Israel's role in maintaining the hamūla's presence in village life, Rosenfeld argued:

The large number of Arab laborers working for wages outside the village, the growing number of merchants throughout the country, form groups which cross-cut hamule ties and signal the development of classes. Yet the State continues to emphasize its ties with the hamayil generated during the feudal regime. It thus upholds and reinforces the traditional structure of the village through its maintenance of a form of paternalism which makes use of social groupings and their leaders that are tied to the economic and political organization of the past $(1964,231)$.

Rosenfeld thus emphasizes the hamūla's ties to the past, interpreting marriage and inheritance practices as remnants of the practices of a kinshipbased society, and Israel's role in maintaining the hamūla's historical structure. Rosenfeld did recognize the role of wage labor and Israeli government interference in creating some change, but argued that these factors caused "nonradical and impeded change" (1968, 741). For example, Rosenfeld argued that family fission was likely to occur earlier than in the past because wage labor gave sons a greater degree of independence from their fathers; yet practices such as bride price should be understood as "linchpins of an ongoing, and moribund, structure" $(1968,740)$. Villagers are not presented by Rosenfeld as actors in their own right, but as manipulated by the Israelis to remain tied to their "traditional" way of life.

Cohen (1965), in his study of a Palestinian village located between Haifa and Tel Aviv inside Israel, also emphasizes the hamūla's historical continuity, but in contrast to Rosenfeld, outlines the different ways in which the hamūla has dramatically changed in response to recent historical events. Cohen argued that Arab village social structure underwent three distinct periods of change. First, under the Ottomans, the hamūla played a central role in peasant life, forming the lines according to which "dominant cleavage" in the village took place politically and socially $(1965,8)$. Under the British Mandate, however, the hamüla lost much of its economic base and social power as peasants lost land:

With the conversion of a great proportion of joint estates to private ownership, the hamula lost its economic basis. The new lines of stratification cut across hamula boundaries and tended to disrupt the hamula. The development of an Arab countrywide nationalist organization weakened the hamula further by the creation of national associations that cut across particular patronymic and territorial groups. The 
dominant cleavage in the village ran on class lines $(1965,8)$.

Families of similar economic status thus "developed closer connections with each other than with the other families from their own hamula" (Cohen 1965, 46).

In the third period examined by Cohen, beginning roughly in 1950, "Despite the development of some economic and political conditions which should have completed the disruption of the hamula, there was a revival of intensive hamula activity... There was renewed emphasis on the norms of patriliny. ... Once again the dominant cleavage in the village ran on hamula lines" $(1965,9)$. This change in the structural orientation of the village, from class to hamūla identity, was brought about by certain changes in Israeli government policy as well as "the existence of some social and cultural continuities from the past" (Cohen 1965, 105). In particular, the establishment of the "Committee of Labour" in the early 1950s was undertaken by the Israeli authorities to try to increase their support in the village by not allowing any single hamūla to become too powerful, thereby alienating members of other hamāyil in the village. The Committee would allot jobs to the various hamāyil in numbers proportional to their size (Cohen 1965, 67). In 1959 the establishment of the village council system by the Israelis further strengthened the roles of not only large, powerful hamāyil in village life but also the small ones by allowing each hamüla some say in the governing of the village (Cohen 1965, 103). Thus, "competition between the hamulas would certainly continue over some marginal power and prestige, but under the circumstances no single hamula would be able to dominate the village for any length of time" (Cohen 1965, 103). Individuals stood to benefit from drawing on their hamūla membership and competing with those in a hamūla other than their own. Here the hamūla is presented as an enduring structure, able to be revived in its previous form by villagers in response to Israeli pressures.

Echoes of these arguments-the hamūla is an essentially traditional structure, able to be manipulated by the Israelis - are found in the works of other authors as well. Ein Gil and Finkelstein, while recognizing that Israeli occupation hardly allows for autonomy on the part of the Palestinian peasantry in Israel, write:

The zionist (sic) attempt to obliterate and deny the existence of Palestinian national identity brought about a response characteristic of oppressed minorities-the strengthening of traditional structures.... In order to dominate and control the great majority of the members of a hamoulah, it was enough for the authorities to harness the headman to their wagon. A party which could bribe the headman would get most 
of the votes of his hamoulah. In this way the hamoulah structure was turned from a stronghold of resistance to zionist policy into the institutional framework through which zionist domination over Palestinian society is mediated $(1977,17)$.

The hamūla is presented here as a tool for the Israelis, with hamūla members having little or no ability to resist such outside interference or manipulation by the "headmen." Also emphasizing the hamūla's ties to the past and largely immutable character, Ma'oz explained the elections of 1955 in the West Bank thus:

Local politics within the West Bank were based largely on inherited group characteristics such as family, religious, and village ties. These became the important social attributes for municipal politics in accord with the level of socio-economic development and the conservative cast of West Bank society. The hamula, the extended family, or clan, constituted the major political unit and force in local West Bank politics and dominated voting patterns and the formation of municipal councils.... As a result, the successful contender in city elections needed the support of the major families as their political importance overshadowed the significance of the candidate's own qualities; thus, the oligarchical nature of West Bank local politics, based on the social dominance of traditional elements, was a further obstacle to the creation of a democratic municipal regime (1984, 49, emphasis mine).

Here the power of the hamūla is recognized but not problematized; nor is the larger context of Jordanian occupation taken into account.

Cohen's work makes an important break with Rosenfeld's, however, in recognizing that the genealogical structure of the hamūla significantly differs from the structure of patrilineages. Cohen describes the hamūla as "a patrilineal association whose members ... lived in the same quarter, within the same villages, and they co-operated on a number of specific occasions" $(1965,3)$. Cohen thus used the term patronymic group to reflect that the common use of a name of an agnatic ancestor provided hamüla members with a sense of shared identity $(1965,105)$. To explain membership in the hamüla, Granqvist also argued for the use of memory and consciousness in creating a shared hamūla identity, as opposed to a strict application of lineage theory: "It is interesting to see that the fact of a common origin is not enough but people must be clearly conscious of it. As soon as the memory of the common ancestors becomes dim, the bond by which blood relationship is conditioned begins to loosen" (1931, fn. 80). By explaining the ways in which the names of families have changed over the decades, Granqvist further emphasized the nature of hamūla identity as dependent on memory and its malleability. Granqvist thus noted that while the definition of nasab is lit- 
erally, "relationship-in-law," its wider meaning is "a bond between families by marriage between its [the hamūla's] members." Occasionally, it is necessary to create an appropriate genealogical context, particularly for constituting new marriages (Granqvist 1931, 86-87). Similarly, Antoun argued that "the village is viewed as a genuine web of kinship rather than a series of discrete patrilineal descent groups on the one hand or a series of marriage alliances on the other" $(1972,116)$. More recently, Atran uses the term "patronymic groups" as opposed to strict genealogical reckoning (Atran 1986, 272), stating:

The constituent patrilineal units (jeb) of any one hamula (sic) are rarely connected genealogically. These units vary in depth but never encompass fewer than two, and almost never more than five, generations; and it is recognized by one and all that few, if any, of the component jeb of a hamula are of the same 'sinew' ('asab). As for general social relations between hama'il these are usually phrased in idioms of affinity (nasab) and matrilaterality (makhwal) although relations between groups having the same patronym, but belonging to different villages . . . are expressed in terms of patrilinearity (e`ammam) $(1986,274)$.

An example of a similar reckoning of relations is seen in Granqvist's discussion of branches of one hamūla in Artas:

They could not state the exact relationship between these three fathers: 'Öde, Ahmad and As'ad Reya; and they solved the difficulty by saying that they were brothers although of different mothers, a fact of a certain general genealogical interest but in any case much too vague to be accepted, especially when one knows how wide is the meaning of the word brother, which is sometimes applied to all men in the same village (1931, 80 fn. 1).

Although Eickelman $(1989,155)$ credits Cohen with being "one of the first ethnographers to break with the more conventional assumptions of lineage theory in a Middle Eastern context," Granqvist may in fact have set the precedent for Cohen's later work.

While distinguishing the nature of the hamūla from a patrilineage is important, Cohen, Rosenfeld, and others nonetheless emphasized the functioning of the hamūla as a timeless source of identity for villagers which made them easily vulnerable to Israeli manipulation. In contrast, Nakhleh has argued for "the need for demystifying and dismantling widely held assumptions concerning the pre-eminence of the hamula" $(1977,54)$. Authors such as Rosenfeld, claimed Nakhleh, focus on "the immutable nature of the traditional Arab social structure [as] the major factor impeding the process of substantial social change" $(1977,65)$. While Rosenfeld does recognize some degree of change as brought about by Israeli government policy, his analysis 
does not go far enough: Nakhleh described Rosenfeld as "curiously coy in subjecting the dominant ideological factor, i.e., Zionism, and the specific policies of the government of Israel towards the Arab village to the same type of analysis [as he employs for his analysis of the Palestinian village family]" (1977, 66). Similarly, Lustick argues that studies

comparing the increased vigour of Arab village hamulas, or clans, in Israel compared to their declining political role before 1948, or research documenting trends in intra-hamula marriages, take on added significance when considered in conjunction with Jewish attempts to reward and support traditionalist elements in the Arab sector $(1980,70)$.

Without explicitly considering the policies of the Israeli state and how they may have affected the hamūla, researchers "adhere to the dominant ideological configurations by which the people under study are subjugated" (Nakhleh 1977, 67).

In a similar vein of critique, but shifting the argument to a class analysis of the hamūla, Asad argued that "'the hamula' of Israeli Arabs was the ideological resolution of a Zionist problem-for it constituted a mode of control and an imputed identity for the only political existence allowed to Arab villagers in Israel." He went on to suggest that "it is in terms of class as a theoretical concept, not of hamūla as the so-called 'traditional form' of Israeli Arab organisation, that we can hope to comprehend this problem" (1975, 274). Indeed, based on his analysis of Palestinians' class position inside Israel, land expropriations, and the depression of Israeli Arab agriculture, he argued that "at no point in the entire period under consideration is the hamula a basic principle for the political economy of the Palestinian peasant" $(1975,270)$. Rather, class is the defining factor of identity for Palestinian villagers; the hamüla is a creation of Zionist policy in its attempts to manipulate the Palestinians (ibid.).

Yet, viewing membership in a hamūla as a class identity does not explain why the hamūla itself has been maintained by villagers, particularly in cases when hamüla membership cuts across economic lines within a single village. On the other hand, Cohen and Rosenfeld rely too heavily on an essentialized view of hamūla identity, arguing respectively that such an identity has been simply "revived" or "preserved" from an earlier time period. Contending that the hamüla is primarily the creation of the Israeli state, however, and that hamūla identity is now a class structure, Asad commits the same error as Cohen and Rosenfeld: the dialectic between history and the present time is not resolved. Equally problematic, however, is the relationship between 
the degree of control exercised over the hamüla by the Israeli state and the degree of resistance and autonomy demonstrated by Palestinian villagers. It is unlikely that Palestinian villagers should be analyzed as simple pawns in the hands of the Israelis tied to their "traditional" ways of life or as free from their historical underpinnings as hamūla members.

\section{The Hamūla: Later Approaches}

Following these early works, later anthropologists have focused increasingly on examining the hamūla and hamūla identity with greater specificity, moving away from a focus on hamūla structure to the histories of particular villages and how those histories have shaped the interactive nature of family and class identity.

For example, Salim Tamari (1981) examined the impact of the increase in wage labor on West Bank village social structure and the family farm. His argument, however, moves beyond Rosenfeld's reliance on a "timeless past" to explain the continued reliance of the Palestinian peasantry on the traditional family structure. Noting that the majority of Palestinian villagers are involved in unskilled construction work in Israel, while urban Palestinians are more likely to be involved in industrial labor, Tamari nevertheless asserts that "it would be a mistake to consider the new transformation as constituting the creation of a rural-based proletariat" $(1981,39,60)$. Rather, the Palestinian villager/worker is characterized by an "ambivalent class identity" based on his transitional status (Tamari 1981, 60). This ambivalence, according to Tamari, can be accounted for by six factors:

(1) Family and clan connections are central factors in recruiting villagers to work in Israel. Typically, a team of Arab construction workers in Israel will consist almost entirely of family and clan members (Tamari 1981, 60). Tamari argues that "this constant interaction with, and dependence on, his kin reinforces the worker's village identity" (ibid.);

(2) The unstable nature of the work in Israel;

(3) The internal hierarchies present among village wage laborers (i.e., that certain villagers will be hired by the Israelis to hire their family and clan members to work) creates "not only a sense of 'false consciousness' among rural workers, but an efficient system of labour management in the absence of workers' organizations and work tenure stability" (ibid.).

(4) Wage labor has actually contributed to a "new homogeneity in the village class structure" (ibid.). This is because social differentiation based on land ownership has greatly diminished as wage labor has increased in importance as a source of wealth; wealth based on wage labor, however, has not become the basis of significant class differences (ibid.).

(5) While some villagers have accumulated cash wealth from wage labor the op- 
portunities for economic investment in the rural areas remain very limited.

(6) In the context of unstable work opportunities, family land is an important source of security; in agreement with Rosenfeld, Tamari argues that the seasonal nature of agricultural work allows the villager to work for wages and work on the land as necessary (ibid.).

Tamari, quoting Ammons (1978), argues that emigration and peasant workers have contradictory consequences for the peasant household. Migration contributes to a strengthening of the extended unit and a conservative social outlook among the family members who remain at home (Tamari 1981, 38). On the other hand, commuting has "hastened the process of breakup and nuclearization, in part because younger bread-winners in the family established a source of earnings independent from their fathers" (Ammons 1978, 213, 219; quoted by Tamari 1981, 38). In his research in one particular village, Tamari found that the two main village factions continued to be concentrated in separate areas of the village, suggesting that hamūla identity continues to differentiate villagers; however, at the entrance of the village new homes from both factions intermingled (Tamari 1981, 44). Tamari thus accounts for the ambiguity of villagers' class and hamüla status without relying on a fixed notion of the force and continuity of the past.

Migdal (1980a), like Tamari, relies on a political economy approach for his analysis of identity and social structure in Palestinian villages. He thus examines three trends in villages stemming from the availability of work in Israel after 1967 and the existing and historical social structure of villages located in different geographical areas in the West Bank. For example, in the first trend, in villages which were already highly stratified, old social divisions based on who did or did not own land were dramatically reinforced primarily by the wealthy land-owning groups sending their sons to Europe (Migdal 1980a, 76). Those who do not own land move up the economic scale due to their work inside Israel. However, they continue to be denied positions of power by the older, land-owning class: "The village landowners have used the larger political situation as a conservative tool, making any new claims to village leadership illegitimate for the duration of the occupation" (Migdal 1980a, 69). Migdal only hints at the role of a specific hamūla identity in shaping conflict: "Cleavage was talked about in we-they terms, referring to village status groups, but, nevertheless, most issues of status continue to be thought of in highly personal (or, more properly, familial) terms" (Migdal 1980a, 69).

In the second pattern, the village was not significantly stratified in the past and only a small number of young men were sent to the West to be educated. 
The availability of work in Israel has not dramatically changed families' fortunes, as even under the Jordanians, villagers migrated to other parts of the Middle East for work. Thus,

work in Israel has merely served to extend patterns begun during Jordanian rule and has created few new conflicts. The new houses in the village have been built by men who went to Kuwait starting in 1955 and, more recently, by those working in Israel.... Those who could not or would not gain prosperity through long-term migration have succeeded in staying in step through daily commuting to Israel (Migdal 1980a, 71-72).

Clashes have been generational, rather than class-based, in character. Migdal attributes this to the effect on young men of working in Israel: "As young West Bankers have become more educated and have been exposed to the technological and social phenomena in Israel, they have begun to view the old generation as an obstacle to modernity" (1980a, 72).

Finally, Migdal identified villages which were not highly stratified in the past, and which contained a significant number of young men who were educated in the Middle East but remained in their villages. In these villages the landowning leadership adopted policies of "accommodation and cooptation" for the newly wealthy who took work in Israel (1980a, 74). In these villages "homogenization of social structure has been most rapid, and conflicts based on status and generational cleavages have stayed at much lower intensity" (Migdal 1980a, 77).

Migdal removes the hamūla completely as a focal point for his argument, attending instead to the role of economic and generational cleavages in villages. Yet, by doing so, he too leaves questions about why hamūla identity may in some cases be maintained at all, cutting across class and generational lines-unless, of course, in all the cases he examined none of his informants in fact referred to the hamūla. Migdal does, however, blend a historical analysis into his argument without homogenizing villagers' different experiences of the past.

In contrast to Migdal, Escribano reintroduces the hamūla into her discussion as a source of identity, but, unlike some of the earlier anthropologists discussed above, avoids an analysis which relies too heavily on the hamūla as a product of the past. Escribano carried out research in two Palestinian villages in the early 1980 s which greatly differed in their hamūla relations, including marriage patterns, inter-clan feuding, and overall wealth. Kober, the first village examined by Escribano, is a relatively isolated village in the West Bank. Migration is limited and the village is economically depressed. In the village there are two large hamūlas, the Fellahin and the Bargouthi 
(Escribano 1987, 118). There exists significant antagonism between these two clans, stemming from a history of feuds over land claims and political alliances. Each clan lives in a different section of the village, except in the newest part of the village where a few houses intermingle (Escribano 1987, 122). The young people who are from the different hamūlas and live side-by-side, however, claim they would not marry across hamūla lines (Escribano 1987, 122). There were three inter-hamūla marriages in the village, all of which involved Fellahin men and Bargouthi women from another village (Escribano 1987, 136). Of the fifty women Escribano interviewed in Kober seven, or fourteen percent, were married to their first patrilineal cousins $(1987,131)$.

In Deir Dibwan, the second village studied by Escribano, there is little antagonism among the three hamāyil in the village $(1987,125)$. Men tend to migrate for longer periods of time than men in Kober, "broaden[ing] the sense of reference for the villagers" (Escribano 1987, 142). The villagers own more land in Deir Dibwan than do the villagers in Kober. Marriages among the different hamāyil are common (Escribano 1987, 139). A number of men had married foreign women who returned with them to the village. Escribano found that only one woman out of fifty she interviewed was married to her first patrilineal cousin $(1987,131)$. In Deir Dibwan, the accumulation of wealth primarily from male migration has created a link between wealth and honor; further, for villagers "solidarity based on the hamoulleh has shifted to the village level" (Escribano 1987, 148). Escribano claims:

The Deir Dibwan Association, headquartered in San Francisco, provides an example of this phenomenon. Membership in this association is not limited to any specific hamoulleh. The Association has representatives from each of the village hamoulleh as well as a representative from the refugee groups living in the village. Such membership represents a source of honor for those in the United States and for their relatives in the village. . . . These Associations serve multiple purposes: as a link to the villages, as a source of identity to its members, to increase their members' honor and to increase the villages' honor as well. (1987, 147-48).

In Kober, hamüla identity remains more central than village level identity as is the case in Deir Dibwan; thus, practices of clan endogamy in Kober are a central source of honor, as are collective actions in response to conflicts which arise between the two hamüla (Escribano 1987, 147).

Escribano's separation of these two levels of identity-village, and hamūla-begs certain questions, including how these identities depend on and interact with one another, what other "levels" of identity there are in a 
village, particularly the role that class consciousness might play, and how villagers may use such layers of identity differently in different situations. By dichotomizing "village" and "hamüla" identity, we gain little sense of how the two may be interdependent and what other kinds of factors may influence social relations. Yet the works of Escribano, Migdal, and Tamari speak to the need for a careful examination of history, economy, and politics for understanding the nature of the hamūla and its regional variation.

These works, although variable in their approach, focus on the public expressions of the hamūla in the dominant discourse of village life. This focus excludes discourses which do not often receive public recognition, but are nonetheless important. As I argue below, while village women may share in the expression of this dominant discourse at appropriate moments, a deeper consideration of women's experiences and perspectives adds an important dimension to understanding the nature of social ties in practice.

\section{The Status of Women}

The literature on the hamūla is largely missing a careful consideration of women's lives and the ways in which women may conduct their relationships; indeed, in the early anthropological literature there are relatively few studies of any sort which consider women's status and their relations to one another. A typical example, however, of the few arguments present in the literature can be seen in the following statement by Lutfiyya: "In a patriarchal, patrilineal, and patrilocal society, such as the one under study, it is quite clear that the social position of women is expected to be inferior to that of men. This is generally true, although, as we shall see, women in this society are endowed with certain rights that assure them of some protection against the tyranny of men" $(1966,146)$. The rights generally focused on by anthropologists include in particular women's rights to inherit property (Moors 1995, 1). Thus Rosenfeld argued (1960) that the two determining factors of women's status in Palestinian villages are kin and property relations. The nature of women's relationships to one another, which may suggest various status positions held by women within the community, are largely overlooked. When such relationships are accounted for, there is a tendency for discussion to rely on stereotypes of women as competing and jealous or as indistinguishable from one another.

Rosenfeld claimed that the male-dominated inheritance system both protects women and denies them their rights: women are forced to forfeit their share of the family inheritance to receive life-long protection from male kin and certain rights. Examples of the benefits stemming from a woman's refusal of her inheritance include the freedom to be a $z a^{c} l \bar{a} n a$ woman (a 
woman who returns to her father's house when she feels her husband is unjust), to enter her father's house and take food that she needs, and 'idìya, the obligation of her brothers to give her gifts twice a year on the occasion of the major feasts (also noted by Granqvist 1931; Rosenfeld 1960, 67). If the woman should claim her share of the inheritance, however, she forfeits her kin rights, a consequence which Rosenfeld suggests is a great tragedy for the woman $(1960,67)$. Women, therefore, Rosenfeld argued, are "reduced to reliance on kinship" (1960, 70), a perspective on women's lives which stresses the utilitarian value of kinship.

Rosenfeld suggests ways in which a brother may be dependent upon his sister, but focuses his argument on the near-total reliance of the sister upon her brother and male kin for protection throughout her life. This trivializes men's complementary dependence on their sisters. Indeed, while a woman's tie to her family for protection is strong, Rosenfeld in fact notes at one point that the brother's tie to his sister is economically greater $(1960,68)$. This is because he is dependent upon her for his own marriage either by using her in exchange for a bride or using her bride-price for his own (also noted by Granqvist 1931, 137-39); also, a brother relies on his sister's forfeiting her inheritance claim, thereby increasing his. Granqvist, as noted above, also provides evidence of a brother's reliance upon his sister and the interlocking nature of responsibility to each other this entails. Brothers and sisters can also be understood as practicing a kind of "masked reciprocity" due to their dependent relationship upon one another. Occasions such as gift-giving between men and women are characterized by "the on-going indebtedness of the men to their sisters; males take females' property and they marry on their account" (Rosenfeld 1974, 159). Exploring the ways in which family members depend on one another and create relations of reciprocity may be a useful and more sensitive tool for analyzing factors of women's status.

In terms of women's relationships to one another, authors generally claim that parties are commonly antagonistic, vying for status and favors, or approximately equal in their relations. Rosenfeld (1974) argued that women maintain primarily egalitarian relationships with one another while men engage in hierarchical relations. Among women, Rosenfeld argued, "the give and take of reciprocity emphasizes the basic equality that exists among them. That is, there is not status hierarchy between peasant women in the village other than that which may exist within an extended family" (1974, 140). These extended family hierarchies focus on age and the demonstrated ability to bear sons. Yet women believe, according to Rosenfeld, that "one woman is as good as the next"; they see "their common condition" and em- 
phasize it $(1974,149)$. Women struggle "not to allow a status hierarchy form among them. They do not allow a woman to assume the status of a man. ... They measure everything and every woman; they demand equality, which they personalize, and the smallest distinction among them does not go unnoticed" (Rosenfeld 1974, 149). Men, on the other hand, are "involved in a ceaseless struggle for positions in a village-wide status hierarchy and translate the demands of reciprocity into distinctions between themselves" (Rosenfeld 1974, 140). Men are separated by material differences, including the property-owning father and the propertyless son, or simply poor and rich families. Thus rich men and poor men interact in status-defined ways in practices of reciprocity; men differentiated by wealth "could not but be involved in internal struggles for individual status positions, authority, and economic advancement; the format of reciprocity provided one of the means of expressing inequality as well as equality" (Rosenfeld 1974, 154).

Rosenfeld concludes his 1974 article by noting that changes in the village are changing the nature of these reciprocal relationships. Men "try to preserve the fictions of the past status hierarchy [but] the effect of the economic and occupational transformation of the village has been to have men regard themselves as equals" (Rosenfeld 1974, 161). Thus, men, like women, see themselves as essentially equals. The only exception to this among women are the few women in the village who have become "citified" and therefore "more reserved in expressing reciprocal behavior" (Rosenfeld 1974, 16162). Finally, Rosenfeld claims that the wife's sense of individuality and selfimportance, traditionally derived from her kin, is decreasing as gift-giving becomes more oriented towards the household as a whole and less towards the individual $(1974,162)$.

Rosenfeld and other authors also focus on women as a source of disputes. Cohen wrote that women "are often a source of disputes. The intense and complex relationships created by in-hamula marriages strain the relationships of patriliny in a variety of ways" $(1965,124)$. As part of her husband's family household, a young woman is under the authority of his father, mother, and brothers. This creates tension particularly between the motherin-law and daughter-in-law; while the mother-in-law struggles for the unity of the extended family household which allows her to maintain her power, the daughter-in-law works to escape the authority of her mother-in-law by setting up her own household. Thus a young married woman will often pressure her husband to separate from his kin and establish his own household so she may reach "the structural situation that she has constantly striven for wherein the only real authority over her is her husband" (Rosenfeld 1960, 68). While Granqvist notes that villagers believe that all kinds of kin can be 
a "heavy burden and most troublesome," she also highlights that men, like women, may experience difficulties with their mothers-in-law (1931, 93). More recently Haj wrote, "A young bride enters her husband's household at an extreme disadvantage as she will be subordinate not only to all men in the family but also to senior women, especially her mother-in-law. . . . Indeed, a bitter rivalry between mothers and daughters-in-law within this household is not uncommon" (1992, 763-764). Yet Haj also notes that a sex-segregated world allows women "to foster and maintain their own networks of sociability outside those of men and their marriages. ... These networks in Middle Eastern societies offer women more control over their own world and protect them against emotional and social isolation" $(1992,764)$. Yet in the Palestinian case, networks of women and the systems of support they provide for one another are generally not explored.

Understanding women's lives and relations to each other as well as to men is the pathway to understanding issues of status, strategy, and power among women. This approach, in contrast to that adopted by the studies examined here, would allow for a non-homogenized view of women as actors within their cultural bounds.

\section{Recent Approaches to Studying Palestinian Women}

Studies of Palestinian women have mushroomed in recent years. These studies can be organized into two categories: First, those which deal with the role of occupation and women's involvement in the nationalist movement and, second, works which utilize a political economy and/or Marxist approach to understanding women's lives (Hammami 1995, 18). In both approaches concepts of "patriarchy" and "tradition" are heavily relied upon but not rigorously analyzed (Hammami 1995, 18; see Hatem 1987 and Kandiyoti 1996 for critiques of the use of the notion of "patriarchy" in the study of women in the wider Middle East). In the first approach, authors claim that "traditional society's oppression of women is worsened by the experience of the Occupation" (Hammami 1995, 19). To combat their oppression, women join organizations which work against the occupation, but do not confront directly the issues of their "traditional" oppression. This twotiered approach, focusing on an unproblematized "traditional" society made worse by the outside forces of occupation, can be seen in the following:

The role and status of Palestinian women in the hamula system has been defined by centuries of cultural patterns and social restrictions and justified by religious sanctions. It has also been maintained by local and alien governments ruling the Palestinians, who have utilised this traditional structure as a system of social control in 
order to avoid conflict and facilitate the administration of the conquered territories (Haddad 1980, 148).

The intifada is then understood as a two-tiered rebellion against traditional oppressions and outside forces. For example:

Resistance in the intifada is waged not only against twenty-three years of Israeli military occupation and economic, political, social and cultural oppression of the Palestinians. Women of the intifada are beginning simultaneously to wage a socialcultural struggle against the traditional Palestinian patriarchal structure (Abdo 1991, 22; cf. Fawry 1986).

These authors and others claim to examine these issues of traditional oppression and externally-imposed oppression "simultaneously" but almost without exception focus on the history of Palestinian women's organizations and ignore the details and complexities of "traditional family norms." A central problem with this approach, therefore, is the lack of specific theorizing of key concepts, such as "norms and traditions" or "family honor" as well as an over-reliance on the role that formal organizations play in everyday life for women. ${ }^{3}$ As Gad points out, while during the intifada women in camps were present in large numbers at demonstrations, they were rarely directly involved in regular and sustained committee actions $(1989,17)$. Estimates by the Palestinian Federation for Women's Action Committee in 1989 revealed that only three percent of the number of available women in the occupied territories between the ages of fourteen and fifty were organized by the existing women's committees (Najjar 1992, 151).

In the works of only a few authors have the practices of the occupation and its effects on women been linked to women's experiences of oppression within their families and society: "Thus, women are oppressed by traditional society and then separately by the Occupation" (Hammami 1995, 21). Kandiyoti argues that:

3 There are numerous Palestinian women's organizations, including four large committees which follow the factional lines of the PLO: The Association of Women's Work Committees associated with the Democratic Front for the Liberation of Palestine; the Association of the Palestine Working Women associated the Palestine Communist Party; the Women's Committee for Social Work associated with Fatah; and the Palestinian Federation of Women's Action Committees associated with the Popular Front for the Liberation of Palestine. There are many local women's committees which run outreach programs to women in villages. Two of the largest organizations in the West Bank not definitively associated with a branch of the PLO are the $\mathrm{In}^{\mathrm{c}}$ āsh al-Usra Society, or the Family Rehabilitation Society, and the Arab Women's Union in Bethlehem. 
The historical connection between feminism and nationalism in the Middle East has left an enduring legacy of concerns around the effects of cultural imperialism which has discouraged a systematic exploration of the local institutions and cultural processes, centrally implicated in the production of gender hierarchies and in forms of subordination based on gender. Social science paradigms, namely modernization theory and Marxism (with its dependency theory variants) have unwittingly reinforced this tendency by focusing on macroprocesses of social transformation at a level of generality which rendered an engagement with local cultural specificities irrelevant (Kandiyoti 1996, 18, emphasis mine; see also Hammami 1995, 21).

Interestingly, Hammami recommends that scholars reread early studies such as Cohen and Rosenfeld to understand the ways in which Palestinian society has been directly shaped by the Israeli influence: "A re-reading of some of the literature on Israeli rule of Palestinians within the Green Line through the mobilization of seemingly traditional structures such as hamula and clan might provide a useful starting point for this type of analysis on women under occupation" $(1995,22)$, but this without problematizing the early literature in terms of its over-emphasis on the determinant nature of Israeli influence on Palestinian society (as discussed above).

Hammami herself analyzed the relationship between women's increased use of the veil in Gaza and the growing Islamist movement in the Gaza Strip, providing one of only a few examples which are exceptions to the trend to ignore women's daily life experiences. ${ }^{4}$ A further example is found in the work of Moors (1995). Moors explores the varied experiences women have in terms of attaining property, primarily through inheritance, the dower, or participating in wage labor. She further highlights the circumstances in which women prefer to give up their rights to their inheritance to gain different kinds of advantages or are prevented from taking their share of a family inheritance. Through the use of life histories, court records, and interviews, a sensitive and sophisticated view of women and their relationship to wealth and property emerges from Moors' work, one which allows for women's roles as actors in shaping their lives while, at times, being subject to the considerations of occupation and cultural practice.

The second approach to understanding Palestinian women's lives can be seen in the political economy analysis of women as wage workers. As

\footnotetext{
${ }^{4}$ Wood (1993) provides an analysis of the meaning of being an "ethnic minority" and a "terrorist enemy" for the construction of Palestinian Israeli (i.e., Palestinians who are citizens of Israel) identity; this work suggests fruitful paths for future analyses of the contradictory experiences of identity inside Israel for Palestinians.
} 
Hatem points out, however, analyses which focus on women's roles in production "are largely inadequate for the analysis of the emotional and sexual dynamics of the private world with which women are largely associated" (Hatem 1987, 813). Further, "traditional" forces are called upon to explain why Palestinian women wage workers have not developed a radical class consciousness: tradition "appears in the guise of discourses which attempt to maintain women's identities as economic dependents as opposed to instrumental economic actors" (Hammami 1995, 23). For example:

Subjugation to men in the patriarchal family is a condition which the Palestinian female worker shares with other women and which distinguishes her from her class comrade, the Palestinian male worker. The major source of the vulnerability and oppression of the Palestinian female worker is the family. . . . It is important to remember that the Palestinian woman, particularly from a working class family, is exploited by international capital simply because of its relation to domestic labor (Samed 1976, 2; cf. Haj 1992, 761).

These articles focusing on women's exploited role in the workplace fail to provide an adequate context that might reveal "the distinct dynamic of gender as a social/sexual relation of domination in past and present patriarchal societies" (Hatem 1987, 812).

\section{A New Direction}

The literature on both the hamūla and women's lives is in certain respects problematic. A close reading of the early literature on the hamūla reveals how the hamūla model has been used, alternately, to deny Palestinian villagers agency from above (through Israeli manipulations or tradition) or from below (through essentialist ideas about the hamūla's permanence and changeless quality). Later literature, while paying greater attention to the specific histories of villages within particular political economic frameworks, also presents certain questions. These questions include how village and hamūla identity may be complexly interrelated (as opposed to easily separable strands) and how and why hamüla identity is maintained through the generations. These approaches further tend to overlook the perspective of women, relying on the publicly expressed discourse of the hamūla in village life for their analyses.

The literature on Palestinian women, like the literature on the hamūla, ironically also often overlooks village women's experiences in daily life. It is clear that few analysts have undertaken a sustained examination of the importance and dynamic nature of "ordinary" women's activities and their daily lives beyond the realms of their involvement with women's organizations, waged work or confrontations with Israeli soldiers. Such an approach 
would probe and problematize concepts such as "patriarchy" and "tradition" for these women's lives. We may further ask how women's daily lives are enmeshed in the politics of occupation, oppression, and resistance-stemming not only from external forces but also from within the village itselfand, indeed, how these sources of domination, at times, may work together to the detriment of women's lives (see Rothenberg 1999).

My research addresses some of these issues (Rothenberg 1998). I arrived in Artas intending to study women's relationships within the hamūla. When I moved into my hosts' home, I was thus immediately introduced to the families by whom we were surrounded. It was suggested to me that it would be with the women of these households that I would be socializing and doing my research; other homes were considered too far from our neighborhood, or hära. All of our neighbors were extended family members, I was told. Neighbors, family, they were trusted friends. Or, at least, most of them were.

It took some time for the realization to dawn on me that my family's household was actually the only Dār X hamūla household in an area of Dār Y hamūla households. I was, in actuality, dealing with members of two distinct hamülas in the village. I had not, until I finally sat down to draw the genealogy, realized the division. It was not relevant, or more precisely, it was at times only peripherally relevant to the practices of women in particular in daily life. Even once I clearly knew who was in which hamūla I still had trouble trying to clarify how they behaved differently towards those who were not part of their own hamüla in the course of daily interactions. I was constantly led to question what exactly it meant for women to belong to a hamūla.

Indeed, I became increasingly intrigued by the more implicit principles structuring village women's practical relationships. These implicit perspectives provide both a contrast and complement to the literature reviewed here which emphasizes men's understandings of the hamüla, or, what may be described as the dominant discourse of social relations in village life (and thus at appropriate times taken up by women also).

Moving beyond-and behind-the delineations of the hamüla to understand women's relations, allowed me to see what I have termed the centrality of social geography and its logic, or, in other words, how the geographical location of neighbors, friends, and family as well as notions of relatedness create ties and shape the way women practice and experience social relations. The hāra thus also emerges as a central force in women's creation and maintenance of social relations, as does the force of personal preference. Indeed, freed from the constraints of looking to genealogies to explain the 
practice of social relationships (albeit due primarily due to my initial confusion in the village), I looked first to the relationships of those around me and only later at the formally reckoned genealogies as one factor among many for understanding those relations.

The notion and importance of the hamūla as a genealogically-based entity for women's social lives is, at times, clear to any observer of village life; yet the importance of this notion for women's social relations is continuously challenged by other aspects of women's lives which shape their daily relations. Women, therefore, may use the language of the hamüla as an idiom for describing the relationships which are important to them, whether or not a kinship tie exists. While the literature reviewed here presents important interpretations of the dominant discourse on social relations-the language of the hamūla-recognizing the more implicit perspectives on social life complements this picture. Further, this approach knits together an approach to both the hamūla and women which makes women's practices central to understanding family life, and may suggest a future path of inquiry for men's relations as well.

Further, in contrast to the literature on women's status in villages reviewed here, I found my research focusing to a great extent on the ways in which women control other women's lives, as well as the way in which men dominate the lives of women. With the exception of periods of closure by Israel which are recognized as unusual and undesirable, Artas is, during the greater part of the day, a village filled with women, the elderly, and children. Notions of patriarchy clearly expressed in the literature were difficult for me to locate in obvious ways, as there were few men around. Men emerged in the evenings, sitting and talking with one another and their extended family members. Patriarchy is a factor of village life, but so too is the notion that women oppress (and support) other women - and, indeed, the variation on these two central themes is endless. Yet the degree to which women's lives are deeply entwined with one another struck me as central to village life, at least as central as the issue of patriarchy which receives far greater attention in the literature.

Literature which addresses the hamūla and issues concerning patriarchy and women's status as separate areas of inquiry informed my thinking as a first-time fieldworker in Artas. Yet the progress of my own research on the nature of family ties and women's lives often jarred with what I expected to find based on my reading of the literature discussed here. My efforts therefore turned to examining the notions and politics of family and place which are central to women's lives. This research may be seen as striving to bridge the gap between these two zones of theory-hamüla and women's lives and 
status - generally held separate, constituting both a departure from existing viewpoints and, to be sure, material for future criticism by scholars thinking about these issues.

\section{REFERENCES}

Abdo, Nahla. 1991. Women of the Intifada: Gender, Class and National Liberation. Race \& Class 32(4):19-44.

Abu-Lughod, Lila. 1989. Zones of Theory in the Anthropology of the Arab World. Annual Review of Anthropology 18:267-306.

Ammons, Linda. 1978. West Bank Arab Villages: The Influence of National and International Politics on Village Life. Ph.D. dissertation. Harvard.

Antonius, Soraya. 1979. Fighting on Two Fronts: Conversations with Palestinian Women. Journal of Palestine Studies 8(3):26-45.

Antoun, Richard. 1972. Arab Village: A Social Structural Study of a Transjordanian Peasant Community. Bloomington: Indiana University Press.

Asad, Talal. 1975. Anthropological Texts and Ideological Problems: An Analysis of Cohen on Arab Villages. Economy and Society 4(3):251-82.

Atran, Scott. 1986. Hamula Organisation and Masha'a Tenure in Palestine. Man 21(2):271-95.

Augustin, Ebba. 1993. Palestinian Women: Identity and Experience. New Jersey: Zed Books.

Bendt, Ingela, and James Downing. 1982. We Shall Return: Women of Palestine. London: Zed Books.

Cohen, Abner. 1965. Arab Border-Villages in Israel. Manchester: University of Manchester Press.

Eickelman, Dale. 1989. The Middle East: An Anthropological Approach. New Jersey: Prentice Hall.

Ein Gil, Ehud, and Aryeh Finkelstein. 1977. Changes in Palestinian Society. London: Ithaca Press.

Escribano, Marisa. 1987. The Endurance of the Olive Tree: Tradition and Identity in Two West Bank Palestinian Villages. Ph.D. dissertation. Harvard University.

Fawry, Didar. 1986. Palestinian Women in Palestine. In Women in the Mediterranean, ed. M. Gadant, 72-85. London: Zed Books.

Gad, Islah. 1989. From Salon Ladies to Popular Committees: Women in the Uprising. In Readings in Contemporary Palestinian Society Vol. II, 75-103. Bir Zeit: Bir Zeit University Press.

Giacaman, Rita. 1982. Palestinian Women and Development. Bir Zeit: Bir Zeit University. 
Giacaman, Rita, and Muna Odeh. 1988. Palestinian Women's Movement in the Israeli-Occupied West Bank and Gaza Strip. In Women of the Arab World, ed. N. Toubia. New Jersey: Zed Books.

Granqvist, Hilma. 1931. Marriage Conditions in a Palestinian Village. Helsingfors: Societas Scientiarum Fennica.

- 1935. Marriage Conditions in a Palestinian Village II. Helsingfors: Societas Scientiarum Fennica. 1947. Birth and Childhood among the Arabs. Helsingfors: Söderström. . 1950. Child Problems among the Arabs, Studies in a Muhammadan Village in Palestine. Helsingfors: Söderström.

. 1965. Muslim Death and Burial. Helsingfors: Societas Scientiarum Fennica.

Haddad, Yvonne. 1980. Palestinian Women: Patterns of Legitimation and Domination. In The Sociology of the Palestinians, ed. K. Nakhleh and E. Sureik, 147232. London: Croom Helm.

Haj, Samira. 1992. Palestinian Women and Patriarchal Relations. Signs 17(4):76178.

Hammami, Rema. 1995. Commentary: Feminist Scholarship and the Literature on Palestinian Women. Gender and Society: Working Papers (June):17-26.

Hatem, Mervat. 1987. Class and Patriarchy as Competing Paradigms for the Study of Middle Eastern Women. Comparative Studies in Society and History 29(4):81118.

Hiltermann, Joost. 1991. Behind the Intifada: Labor and Women's Movements in the Occupied Territories. Princeton: Princeton University Press.

Jiryis, Sabri. 1976. The Arabs in Israel, trans. Inea Bushnaq. New York: Monthly Review Press.

Kandiyoti, Deniz. 1996. Contemporary Feminist Scholarship and Middle East Studies. In Gendering the Middle East, ed. D. Kandiyoti, 1-28. New York: Syracuse University Press.

Lockman, Zachary, and Joel Beinin. 1989. Intifada: The Palestinian Uprising Against Israeli Occupation. Boston: South End Press.

Lustick, Ian. 1980. The Quiescent Palestinians: The System of Control Over Arabs in Israel. In The Sociology of the Palestinians, ed. Khalil Nakhleh and Elia Sureik, 64-83. London: Croom Helm.

Lutfiyya, Abdullah. 1966. Baytin: A Jordanian Village. The Hague: Mouton and Company.

Ma'oz, Moshe. 1984. Palestinian Leadership on the West Bank: The Changing Role of the Arab Mayors under Jordan and Israel. New Jersey: Frank Cass and Co.

McDowall, David. 1989. Palestine and Israel: The Uprising and Beyond. Los Angeles: University of California Press.

Migdal, Joel. 1980a. Book 1: The Effects of Regime Policies on Social Cohesion and Fragmentation. In Palestinian Society and Politics, ed. J. Migdal, 3-96. Princeton: Princeton University Press.

. 1980b. Palestinian Society and Politics. Princeton: Princeton University Press. 
Moors, Anneliese. 1995. Women, Property and Islam: Palestinian Experiences, 1920-1990. Cambridge: Cambridge University Press.

Moors, Anneliese, et al. 1995. Discourse and Palestine: Power, Text and Context. Massachusetts: Martinus Nijhoff International.

Najjar, Orayb Aref. 1992. Between Nationalism and Feminism: The Palestinian Answer. In Women Transforming Politics, ed. J. Bystydzienski, 143-61. Indianapolis: Indiana University Press.

Nakhleh, Khalil. 1977. Anthropological and Sociological Studies on the Arabs in Israel: A Critique. Journal of Palestine Studies 6(4):41-70.

Nakhleh, Khalil, and Elia Sureik. 1980. The Sociology of the Palestinians. London: Croom Helm.

Pedersen, Birgitte. 1983. Oppressive and Liberating Elements in the Situation of Palestinian Women. In Women in Islamic Societies, ed. B. Utas, 172-91. New York: Olive Branch Press.

Peretz, Don. 1990. Intifada: The Palestinian Uprising. Colorado: Westview Press.

Peteet, Julie. 1991. Gender in Crisis: Women and the Palestinian Resistance Movement. New York: Columbia University Press.

Rosenfeld, Henry. 1958. Processes of Structural Change in the Arab Village Extended Family. American Anthropologist 60(6):1127-39.

- 1959. Social Changes in an Arab Village. New Outlook 6 \& 7:42-47, $14-25$.

1960. On Determinants of the Status of Arab Village Women. Man 40:66-70.

— 1962. The Arab Village Proletariat. New Outlook 5:7-16.

- 1964. From Peasantry to Wage Labour and Residual Peasantry: The Transformation of an Arab Village. In Process and Pattern in Culture, ed. R. Manners, 211-34. Chicago: Aldine.

- 1968. Change, Barriers to Change, and Contradictions in the Arab Village Family. American Anthropologist 70(4):732-52.

- 1972. An Overview and Critique of the Literature on Rural Politics and Social Change. In Rural Politics and Social Change in the Middle East, ed. R. Antoun and I. Harik, 45-74. Bloomington: Indiana University Press.

. 1974. Non-Hierarchical, Hierarchical and Masked Reciprocity in an Arab Village. Anthropological Quarterly 47:139-66.

Rothenberg, Celia E.. 1999 Understanding Ghada: The Multiple Meanings of an Attempted Stabbing. Middle East Report 210:10-12.

- 1998. Spirits of Palestine: Palestinian Village Women and Stories of the Jinn. Ph.D. dissertation. University of Toronto.

Samed, Amal. 1976. The Proletarianization of Palestinian Women in Israel. Middle East Report (August):1-7.

Schiff, Ze'ev, and Ehud Ya'ari. 1990. Intifadah. Ina Friedman, trans. New York: Simon and Schuster.

Tamari, Salim. 1981. Building Other People's Homes. Journal of Palestine Studies 
11-12(1):31-66.

Wallach, John, and Janet Wallach. 1990. Still Small Voices. New York: Carol Publishing Group.

Warnock, Kitty. 1990. Land Before Honour. New York: Monthly Review Press.

Wood, Davida. 1993. Politics of Identity in a Palestinian Village in Israel. In The Violence Within, ed. K. B. Warren, 87-121. Boulder: Westview. 